\title{
Child/adolescent caring for the disabled sibling in the family world
}

\author{
Criança/adolescente no cuidado ao irmão com deficiência no mundo da família \\ Niño/adolescente en el cuidado del hermano discapacitado en el mundo familiar
}

\author{
Vera Lucia Freitaga \\ Maria da Graça Corso da Mottab,c \\ Viviane Marten Milbrath ${ }^{d}$ \\ Ruth Irmgard Bärtschi Gabatz \\ Jéssica Stragliotto Bazzan ${ }^{d}$
}

How to cite this article:

Freitag VL, Motta MGC, Milbrath VM, Gabatz RIB, Bazzan JS. Child/adolescent caring for the disabled sibling in the family world. Rev Gaúcha Enferm. 2021;42:e20200153. doi: https://doi org/10.1590/1983-1447.2021.20200153
Universidade de Cruz Alta (UNICRUZ), Centro de Ciência da Saúde e Agrárias, Departamento de Enfermagem. Cruz Alta, Rio Grande do Sul, Brasil.

Universidade Federal do Rio Grande do Sul (UFRGS), Escola de Enfermagem, Departamento Materno Infantil. Porto Alegre, Rio Grande do Sul, Brasil.

Universidade Federal do Rio Grande do Sul (UFRGS), Escola de Enfermagem, Programa de Pós-Graduação em Enfermagem. Porto Alegre, Rio Grande do Sul, Brasil.

${ }^{d}$ Universidade Federal de Pelotas (UFPel), Faculdade de Enfermagem, Programa de Pós-Graduação em Enfermagem. Pelotas, Rio Grande do Sul, Brasil.

e Universidade Federal de Pelotas (UFPel), Faculdade de Enfermagem. Pelotas, Rio Grande do Sul, Brasil.

\section{ABSTRACT}

Objective: To understand the meaning for the child/adolescent of participating in the care of the disabled sibling.

Method: Research in the light of the Heideggerian phenomenological approach, carried out in the northern region of Rio Grande do Sul - Brazil. Twenty children/adolescents who lived with their disabled sibling participated. The information was collected through phenomenological interviews, interpreted in the light of hermeneutics from Paul Ricoeur.

Results: The child/adolescent helps the family in caring for the disabled sibling, in feeding, bathing, dressing, among other activities, at sometimes there is excessive responsibility of the child/adolescent for the care of the sibling.

Final considerations: The inclusion of the child/adolescent who lives with a disabled sibling and their families in the planning and implementation of health care activities is essential. It stands out as a research contribution to the qualification of the practice of health professionals, especially the nurse in the scope of care for the child/adolescent who experience this phenomenon.

Keywords: Child. Adolescent. Disabled children. Empathy. Nursing.

\section{RESUMO}

Objetivo: Compreender o significado para a criança/adolescente de participar do cuidado do irmão com deficiência.

Método: Pesquisa a luz da abordagem fenomenológica heideggeriana, realizada na região norte do Rio Grande do Sul. Participaram 20 crianças/adolescentes que conviviam com 0 irmão com deficiência. As informações foram coletadas mediante entrevista fenomenológica, interpretadas a luz da hermenêutica de Paul Ricoeur.

Resultados: A criança/adolescente auxilia a família no cuidado do irmão com deficiência, na alimentação, no banho, no vestir-se, dentre outras atividades, em alguns momentos observa-se excessiva responsabilização da criança/adolescente para com o cuidado do irmão.

Considerações finais: Constata-se ser imprescindível a inclusão da criança/adolescente que vive com irmão com deficiência e suas famílias no planejamento e implantação das atividades de cuidado à saúde. Destaca-se como contribuição da pesquisa à qualificação da prática dos profissionais de saúde, em especial da enfermeira(o), no âmbito do cuidado à criança/adolescente que vive esse fenômeno.

Palavras-chave: Criança. Adolescente. Crianças com deficiência. Empatia. Enfermagem.

\section{RESUMEN}

Objetivo: Comprender el significado para el niño/adolescente de participar en el cuidado del hermano discapacitado.

Método: Investigación a la luz del enfoque fenomenológico heideggeriano, realizada en una región al norte do Rio Grande do Sul - Brasil. Participaron veinte niños/adolescentes que vivían con su hermano discapacitado. La información fue recolectada a través de entrevistas fenomenológicas, interpretadas a la luz de la hermenéutica de Paul Ricoeur.

Resultados: El niño/adolescente ayuda a las familias a cuidar a sus hermanos discapacitados, como jugar, ayudar con la alimentación, bañarse, vestirse, entre otras actividades, sin embargo, a veces hay una responsabilidad excesiva, para el cuidado del hermano.

Consideraciones finales: La inclusión del niño/adolescente que vive con un hermano discapacitado y sus familias en la planificación e implementación de actividades de atención médica es esencial. La calificación de la práctica de los profesionales de la salud, especialmente la enfermera (0) en el ámbito de la atención al niño/adolescente que vive en estos contextos, se destaca como una contribución de la investigación.

Palabras clave: Niño. Adolescente. Niños con discapacidad. Empatía. Enfermería. 


\section{口INTRODUCTION}

When there is a person with a disability in the family, several transformations occur, redefining roles, in order to (re)organize their ways-of-being-in-the-world ${ }^{(1)}$. Children/ adolescents also experience these transformations, going through processes of confusion and acceptance, and it is necessary to include them in care, so that they can have support to understand the condition of the person with disability and deal with their own feelings ${ }^{(2)}$.

The relationship between siblings is one of the most important and intimate things that human beings maintain in their lives, establishing itself as an essential condition for the psychosocial development of the being and influencing the development of personality, in the family experience, in the perception of the world, in the interaction with the environment and adaptation to the social context. So, having a sibling with a disability creates a risk for the child/adolescent to experience emotional, psychosocial, and physical changes. Often, the child/adolescent feels relegated to the background, ignored and forgotten ${ }^{(3)}$. The nurse has an important role in this issue, being able to develop inclusive care processes that encompass opportunities for partnership with the family, involving all its members ${ }^{(4)}$.

A study carried out with siblings of children with chronic diseases identified that they seek to know the cause of the disease and want to learn how they could help with care. In this context, significant changes occur in the family life of siblings, as they assume responsibilities previously performed by their parents, taking an active role in caring for younger siblings and performing tasks. They often assume the role of pseudo-parents, feeling overwhelmed by extra responsibilities, as well as adopting the role of protectors ${ }^{(5)}$.

A study carried out between people with Down syndrome and their siblings shows that there is good interaction between them. In addition, siblings always try to be present in these people's lives ${ }^{(2)}$.

In this Heideggerian perspective, care constitutes the being, it is the care that shapes, based on the world, the diverse singular forms of existing. From this perspective, care is the movement of living, since the construction of the being takes place as it is being-in-the-world, it is the interaction of this being, as the being is, a being of relationship, since being -in-the-world implies being-in-the-world-with-others and, in this way, all interactions between two human beings modify the way the being is constituted, since it is in constant construction and deconstruction and, in this philosophical perspective, it is believed that care has the role of allowing this (de/re)construction to finitude ${ }^{(6-7)}$.
It is essential to highlight the ingrained relationship between being and time, the human being is a temporal being, he/she is not a series of agoras, he is past, present and future concomitantly ${ }^{(6)}$ what the child/adolescent is is related to his/her past, her present and her future project is intimately linked to the care she received or not. At the same time, the meaning that the child/adolescent attributes to the care of the disabled sibling is related to their understanding of care.

In this context, it is highlighted that care takes place in the daily life of Dasein (Being-there), worrying is an attitude as inherent to Dasein (Being-there) as its condition of beingin-the-world. By the way, Dasein is-in-the-world worrying(6). It can be said that care constitutes the being in its existence. Care permeates all dimensions of existing in the world, because it points to existence itself.

Based on the above, the research question was elaborated: What does it mean for the child/adolescent to participate in the care of a disabled sibling? The objective was to understand the meaning for the child/adolescent of participating in the care of a disabled sibling. This is an excerpt from the doctoral thesis ${ }^{(8)}$, whose objective was: to understand the being-in-the-world of the child/adolescent who lives with their disabled sibling.

\section{METHODOLOGICAL PATH}

This is a qualitative research, in which the theoretical framework of Heidegger's phenomenology was used and for the interpretation of information, Ricoeur's hermeneutics ${ }^{(6)}$. Based on these references, we sought to understand ontologically ${ }^{(6)}$ the meaning for the child/adolescent of participating in the care of the disabled sibling.

The research was carried out at an Association of Parents and Friends of Exceptional (Associação de Pais e Amigos dos Excepcionais - APAE) in a municipality in the northern region of Rio Grande do Sul - Brazil, from November 2018 to March 2019, by a researcher with experience in conducting a phenomenological interview by having studied phenomenology and hermeneutics. To carry out the research at the institution, a letter of consent was previously requested, in which the institution declared to accept the researcher and to execute the study.

The study included 20 children/adolescents who have a sibling with a disability who attends the place of study. The number of participants was delimited based on the sufficiency of meanings to achieve the proposed objective.

The place of study is a philanthropic, non-profit, educational, welfare, cultural, health, studies, and research institution. It is regularly registered with the National Council for Social Assistance and holds a Certificate of Beneficent 
Social Assistance Entity. This team does not have the role of the nurse, however, the primary care nurse is responsible for supporting the institution. It maintains a Specialized Service Center (CAE), where 145 children/adolescents with disabilities are assisted by a Psychologist, Physiotherapist, Occupational Therapist and Social Worker, and a school, in which 88 students are enrolled, at the following levels of education: Early Basic Education (Cycles) and Essential Stimulation. In addition, APAE offers the Blue Space (Espaço Azul) (for autistics), Elementary Education (initial grades), Youth and Adult Education (EJA). As for Human Resources, the entity has 21 employees: nine Teachers, four Service Assistants, a Monitor, a Driver, a Psychologist, two Physiotherapists, an Occupational Therapist, a Pedagogue and a Social Worker.

Inclusion criteria were: being a child/adolescent, brother or sister of a person with a disability; to be 7 years old or older and at most 18; having a sibling aged 3 years or more and undergoing rehabilitation treatment at the institution in the period of data collection; to live with the disabled sibling. And as an exclusion criterion: not being cognitively able to participate in the interview.

The invitation to the participants was initially mediated by the professionals from the place of study, allowing the researcher to get closer to the families of the children/adolescents. After this first contact, according to the family's availability, it was scheduled a time for the researcher to meet the child/adolescent, in which the legal guardians signed the Free and Informed Consent Form (FICF), agreeing with the children's participation. It is noteworthy that none of the guests gave up or refused to participate.

The phenomenological interview was carried out by the researcher, in a place chosen by the participant, being seven at home, in a reserved place and 13 at the study institution, in a room reserved for this purpose, using a script with closed questions (participant code, date of data collection, age of interviewee, age of disabled child/adolescent, number of siblings, age of disabled sibling, age of other siblings, education level, number of people living in the household, religion and type of disability) in order to trace the interviewee's profile, and open for them to speak freely. The question was: Do you help to take care of your brother (your sister)? What do you do? On the day of the interview, doubts that arose were presented, read, answered, and to the child/adolescent was given the Free and Informed Assent Form (FIAF), which was signed by them.

For the collection of information, a phenomenological interview was used, which consists of a process of interaction and dialogue between researcher and participant. In this modality, the interviewee can freely recognize and describe their experience and the meanings given to the situations they experience, related to the research topic $^{(9)}$. The duration of the interviews was approximately 40 minutes each. The interviews were recorded on an MP4 player, then they were transcribed in full by the interviewer, in order to preserve the details of the interview.

For the interpretation of the information, it was opted to use Paul Ricouer's hermeneutics, considering that hermeneutics does not mean only a way of knowing, but of being, the way of this being that exists, understanding ${ }^{(10)}$. It is noteworthy that to interpret, understand a given phenomenon, it is necessary to open up, because to understand a text one must be willing to have it tell you something.

Given the above and the complexity of an ontological interpretation of the being, it aims to explain the steps that were followed during this research to interpret the information collected. Paul Ricouer's hermeneutics does not describe steps, so four steps were used, in view of the didactic easiness, remembering that none of these steps are watertight ${ }^{(11)}$.

$1^{\text {st }}$ step: initial drafting of the text, at that time the transcription of the interviews was performed, transforming what was spoken into written. Afterwards, an exercise of looking at the text was started in order to "appropriate" it. The readings allow contact with the meanings of the text, with the senses and meanings expressed in the words, not only in the written words, but in the description of how they were said, for example, when observing the facial expression, gestures of children/adolescents when talking about the care of the disabled sibling ${ }^{(10)}$.

$2^{\text {nd }}$ step: involvement, at that moment the forms of interpretation were identified. A distinction was made between the spoken and written language, looking for the effects of meaning, making it clear that the text has a multiple meaning, which is only identified when the researcher considers the whole set significant. This step is complex and requires maturity from the researcher to remove from the text what was said by that singular participant, in a unique existential moment ${ }^{(10)}$.

$3^{\text {rd }}$ step: identification of the metaphor; at this stage the objective was to"reconstruct the relationships step by step, allowing the explanation of the effects of meaning, according to an increasing complexity"(10:65). At this stage, it was sought to know and understand the meaning units.

$4^{\text {th }}$ step: appropriation/understanding; here a hermeneutic circle is completed.

The research was approved by the Research Ethics Committee (REC) of UFRGS, under CAAE: 98766018.2.0000.5347 and Opinion No. 2.958.289 of 10/11/2018. It is noteworthy that the researched institution does not have its own REC, for this reason the project was referred to another committee. To ensure the anonymity of the participants, alphanumeric 
codes were used, organized as follows: $\mathrm{C} 1$ to $\mathrm{C} 10$, with the letter " $\mathrm{C}$ " for children and the numbers one to ten consecutively according to the order of the interview, and, A1 to A10, for adolescents, with the letter " $A$ " for adolescents, and numbers from one to ten consecutively according to the order of the interview.

\section{Characterization of participants}

The study participants were 10 children and 10 adolescents, from seven to 18 years old, according to the Child and Adolescent Statute (Estatuto da Criança eAdolescente-ECA), and who live with siblings with disabilities.

The number of siblings of the children and adolescents ranged between one and eleven, and the age of the other siblings between 10 months and 31 years. The level of education between the first year of Elementary School (ES) to High School (HS). With regard to the number of family members, it ranged between three and eight people.

Regarding religion, three people reported not knowing their religion, ten said they were Evangelicals, two Adventists and five Catholics.

Regarding the type of deficiency of the sibling, eight had a diagnosis of cerebral palsy, seven were autistic, three with Down syndrome, one with myelomeningocele and one with unspecified mental retardation.

\section{UNVEILING MEANINGS}

In this dimension, it is presented the meaning attributed by the child/adolescent when participating in the care of the disabled sibling.

Care takes place in everyday life, in practice. There is a practice of care, an ethical scope provided by it. An ethics that springs from the fundamental ontology. Those who care, in effect, manifest their care.

\section{"I help take care of him" (C4)}

The children/adolescents report helping to take care of their disabled sibling, in order to help the mother:

I help take care of him when mother goes to do the dishes. He runs away from the mother, he goes there to play back there, he takes the cart, he goes there, he throws it on the floor, it breaks, then I take care of him [...] (C2).
[...] I help take care of him, whenever mother wants. So, what I do is play with him (brother), the other things, the mother does [...] (C4).

I help. I've also stayed with him so to mother can go out, because most of the time mother leaves him with me, only when he's sleeping. I also play hide and seek with him. I hide and he goes there to find me [...] (C9).

The child/adolescent knows that he/she does not provide care for the sibling alone, she "helps to take care", dedicates ample care/concern that revolves around the disabled sibling, she knows that, especially, the mother is the main caregiver. Care, although a dimension inherent to each one, emanates like a network, creates an atmosphere around the person with disability, which configures responsibility and trust for the other, placing itself entirely in their full attention. In the space where care takes place, there is the possibility of human relationships, through the construction of bridges that allow contact with things and people ${ }^{(12)}$.

Siblings are solid references for the person with disability, in addition to alliances of affection and complicity. In addition to care, they teach, talk and become partners throughout their sibling's development. Care in this context has existential connotations, that is, the sibling is involved in caring for the other and with the other. One is supposed to be interested in the other, and this involves and moves both, completing each other ${ }^{(7)}$.

Care is a way of proceeding with the surrounding entities in the world, called solicitude. It's one relating to the other in an engaging and meaningful way. Solicitude, in turn, encompasses consideration and patience with the other(6). Care is what gives people the condition of humanity ${ }^{(12)}$. The human being lives the meaning of his own life through him. Having patience with the other presupposes the perspective of something that may happen, as can be seen in the following speech:

I help take care of my brother, when my brother vomits, I also caress his little head. [...] when my mother is sleeping I take some food and give him baby food [...]. When my mother leaves him alone [...] I go there to play with him, I get all my dolls and I make a little house for my brother and me to play. [...] I took a little doll and pretended she was my daughter and he was the father. My brother (who would be the doll/baby's father) worked on a motorcycle and I worked as a doctor. Today I played doctor, I was a doctor, I took care of him (brother) and I told him to take 
medicine then he drowned. I makefake medicine and give it to him, my brother and I always play together [...] (C3).

The care for the brother is configured in the sense that something might happen, when she says:"I told him to take medicine". In addition, it can demonstrate the hidden desire for the brother's cure, as when C3 reports:"My brother worked on a motorcycle and I worked as a doctor", this speech can portray the hidden desire for the brother to walk and that, if she is a doctor, she can take care/cure the brother. This is the existential condition of "being-with", being expanded due to care, which, introjected by Dasein, will manifest itself solicitously, deepening the being-with.

The "being-with-the-others" in everyday life, in the sense of care, remains in two extremes of solicitude, the one that dominates the other and the one that puts itself in front of the other in order to free it, and it is called authentic care(6). This care that frees is configured as that for autonomy, capable of enabling the being of care to grow and develop, showing an itinerary and following it at the pace of their steps.

The care for someone belongs to caring as a way of discovering what is being involved; solicitude, in turn, is guided by consideration and patience with the other $r^{(6)}$. Thus, it is understood that the being is unveiled in solicitous care, in which playing is configured as a way of care, enabling Daseín to be himself.

The children/adolescents play and talk with their disabled siblings, there is harmony between them. In addition, care depends on the type and level of dependency/limitation presented, which can, due to its complexity, represent an additional source of stress for the sibling and for the disabled person themselves, thus generating conflict and difficulty in communication between them ${ }^{(13)}$.

Children/adolescents caring for their siblings with disabilities may be forced to adjust their roles in the family, considering their participation in care, it is important to develop awareness of their specific needs and address them. A study points out that the care dispensed to the sibling can become a generator of anguish, due to its complexity and the sibling's condition ${ }^{(14)}$.

In this premise, the child/adolescent's concern with the care of the sibling can generate suffering and anguish. Considering the family context, the difficulties of parents with the person with disability and the early maturation process of the child/adolescent who helps in the care of the sibling, it is perceived that they are not open to the family to express their feelings. Still, often, the family does not have support, such as a network, such as health and education, in order to obtain strategies to address these situations, such gaps can lead to changes in the healthy growth and development of the child/adolescent.

In this context, health professionals can, through the care of these families, identify possible excess responsibility of the child/adolescent, helping families to create strategies to enable their growth and healthier development. Thus, preventing this child/adolescent from putting themselves in situations of unnecessary vulnerability, providing emotional support and strengthening the quality of family-centered care ${ }^{(4)}$.

Thus, the family environment can provide conditions that facilitate the development of children, as they need good quality in family relationships, especially security and affection, more than material conditions. Quality relationships are constituted to beyond the maternal, paternal and extended family functions, through social support, health and education. When experienced in a healthy way, with the establishment of trust, dialogue and expression of feelings, family relationships in the context of the child/adolescent with disability can provide growth, maturation, resilience and empathy ${ }^{(15)}$.

At this conjuncture, nursing can seek strategies with the family for the development of solicitous care, which occurs in a mutual way, so that the child/adolescent helps their disabled sibling in his coming-to-be, and at the same time, feel cared by the family. In this sense, the multi-professional team, especially nursing, can offer face-to-face care to the child/adolescent and their family, through dialogue, understanding, clarifying their doubts, with sensitivity, intuition, in which communication, as a whole, be valued and understood.

Thus, it is believed that the child/adolescent who lives with his/her disabled sibling has a certain "overload" in care, as there is greater responsibility when this "caring" goes beyond playful activities:

Yes. I cool the food for her (child with disability) to eat, put her to bed, play with her. We play hide and seek, tag and cart too. In a tag, I stand still, then she comes and grabs me and says: "got it"! In hide and seek, I'll count and she hides well hidden, there are days when I don't find her [...]. I / help the mother to bathe her too (C7).

I take care of her in the case for mother to work, right. Then when she doesn't have class, she stays at home with me so her mother can go to work. [...]. We live in a two-story house, you know, then when she wants water 
she calls me because she's afraid to go downstairs, then I go down to get her water, I'm taking care of her [...] (A2).

Care is a weaving that goes beyond the dimensions of human reality, as it is woven/dispensed with the demand of each being of care. It can be seen in the information above that $\mathrm{C} 7$ plays and helps in the bath, while A2 supervises playing and meets the demands. Care is related to behaviors, attitudes and acts, which depend on the conditions in which situations occur and the way of relating between caregiver and the being cared for ${ }^{(16)}$.

It is considered that the human being is a unique, singular, integral being, in this perspective, the care given to him must be based on the same premise ${ }^{(7)}$. The philosopher also emphasizes that "if the person is free, care must include freedom. If the person is metaphysical, care should not be solely physical. If the person is a multidimensional being, care must be multidimensional"(7:121).

Caring is helping the other to perform what he cannot do alone. It is to develop an action on the premise of autonomy, so that the other can carry out his own life. It's being with someone, walking side by side with him and keeping pace with their steps, respecting their itinerary and rhythm. Caring is being co-responsible for the itinerary, without defining it ${ }^{(10)}$. It is to help the sibling to be, to reach all his being-able-to-do.

The care relationship between siblings can happen in a healthy way or not, being generally exercised by the older sister. This relationship allows the expression of their ability to care, however, caregivers can lose their condition of child/adolescent. However, despite being able to meet the demands, they are exposed to situations of vulnerability, which can cause psychological and/or emotional damage. Added to this is the fact that they do not always have sufficient support and resources to deal with all these risks ${ }^{(17)}$.

In this research it was observed that the performance of care actions are not aimed only at girls, however, the gender issue is notable, since boys mention more plays in the care of siblings and girls, in addition to these, develop activities such as helping with the bath, brushing hair and providing meals.

When the mother leaves, I take care of her, I put the TV on for her and she watches, I play with her sometimes, when we're alone. I also give her food (A9).

I help, I always help to care. When the mother needs to go out or go to town or anywhere else, I stay with them at home. I took them (the fact of mentioning "them" is because this/and adolescent has two sisters who are autistic) to school when they went to elementary school when the mother couldn't take them, I do anything I need to do, from giving the coffee in the morning, lunch, when the mother needs to do a job, I take care of them, or I did the job for the mother (A10).

Some children are cared for full-time by grandparents, however, in these cases, only one child is under their fulltime responsibility, such as A8 brother, who is also under the guardianship of grandparents and takes care of the brother when they are away:

I help take care of him sometimes, because I'm mostly in the bedroom, you know, but like when grandma needs or is going out, she tells me to keep an eye on the baby. I keep an eye on him you know, but from what I can see he doesn't like to be away from grandma and grandpa, like he keeps looking at me and does it with his little arms (hemade the gesture), where are grandpa and grandma? He asks me for water, you know, he has a habit of asking me for sweets, water, soda, these things he comes and asks me to make coffee, these things for him, you know? He is more attached to food for me (laughs), when he wants something to eat, he comes and asks me. I'venever changed him, but like playing with him when he's needy, these things, when grandma and grandpa go out, I keep an eye on him [...] (A8).

In this context of care, in general, the mother is the main caregiver, with the exception of A8 in which it is the grandmother who takes care of the child with disability, however care remains linked to the figure of the woman. A study carried out with children/adolescents with some type of disability has pointed out the mother as the main caregiver, as well as her burden when developing care and all the demand that a child needs in such conditions ${ }^{(1)}$.

According to a study, which aimed to assess the quality of life and workload of caregivers of adolescents aged 10 to 19 years with intellectual disabilities, women are the main caregivers, with the mother in $82.9 \%$ of cases and, when added to the category"other guardians", $95.1 \%$ females represented the largest number of caregivers, as well as high levels of psychological, physical and mental burden ${ }^{(17)}$.

Another study showed that, in the family nucleus, mothers assume the role of main caregiver most of the time. They present emotional, physical and financial burden, usually because they give up paid work, in addition to restrictions on social and leisure activities(1). 
Thus, it is understood that, even with the goals achieved by women over time, arising from the breaking of taboos imposed by society, cultural aspects in relation to the issue of gender still permeate existence. This aspect also refers to the social issue, in which society dictates the rules for action.

In this context, the female figure is predominant among the main caregivers of children/adolescents with some type of disability ${ }^{(1-2)}$. This context emphasizes the historical and cultural tradition of women in taking the main responsibility for the act of caring, a socially culturally constructed pattern that is still present today, especially in these families. Thus, the child/adolescent caregiver is also constituted by the fraternal relationship, which encompasses a complex world of emotions, feelings of a social, cultural and cognitive nature.

Helping to take care is not always related to playing, these children/adolescents also help with feeding, changing diapers, bathing, preparing the baby bottle, company:

I take care of her. I play and feed her sometimes, sometimes I give her the bottle, then she watches a little and sleeps. Sometimes you have to keep an eye on her, because she doesn't sleep and then goes outside (C5).

I help, I stay with him at home, sometimes I change him (referring to diaperchange), usually I do, [...] I usually play with him too. Sometimes we play outside (C6).

Yes. Sometimes I comb her hair, sometimes she doesn't want to, when she goes to take a shower I also help, but sometimes she fights and doesn't want to (C10).

The activities developed are also based on the learning process, as the child helps the sibling to write and carry out school tasks:

I teach my brother, take my pencils and notebook, and teach my brother how to write. [...] and I take his little hand and I take it like this and he writes, then he makes little drawings, then I take the paint pencil and he paints like that, a few scratches slowly (C3).

Sometimes I help him to take a shower that sometimes he can't do well. He also needs help to do his tasks [...]. He can't read, most of the time we have to read to him and tell him what he has to do. The mother and I helped $\operatorname{him}(A 6)$.
It is observed that C3 helps the brother to write, helps him in a way-of-being, developing authentic care. The concern that does not replace the other, but that anticipates his existential possibility of being, not to withdraw the care, but to give it back. The concern that, in essence, refers to the cure itself, the existence of the other, helping the other to become, in his cure, transparent to himself(6).

Care constitutes the being and its expression in and for the world. Dasein (Being-there) exists played in a facticity that determines their way of being with other entities, in most cases, far from their most originary way of being ${ }^{(6)}$. Therefore, launching oneself into the entire time of existence, understanding it, configures itself as the care of Dasein (Being-there).

A study identified that children/adolescents like to play with their siblings with disability. They help their siblings with self-care tasks, such as helping to get dressed, going to the bathroom, helping with feeding, changing diapers, accompanying them at bedtime ${ }^{(13)}$.

Understanding the other in their dimension is helping him to Be, so the child takes care of their sibling with disability. She takes care because she understands that he/she needs it before he can demand:

Sometimes when he's crying a lot, then I start running with the blanket and he starts running from behind. Or sometimes he takes the baby bottle, then I put the painted chicken on the TV for him to watch [...] (C9).

Ah, when I need to take him to some places, I help to dress him, these things [...] (A5).

Ah, when I can, I help, but now I'm going to start working and I won't be able to help much. But when I'm at home, like [...] he always stays together, we're at the market, he's there or he's at home watching and there's al ways someone close to him. When he wants to watch cartoons, I watch with him, ask for a baby bottle, I do it, normal (A7).

I wake up, have breakfast, sometimes play. As sister (referring to sister with disability) stays at home in the morning, so I go to class in the afternoon, at 12:45 I leave for school and only come back at 5:35 and I spend the rest of the day with her. Sometimes I need to feed her because she doesn't eat with mother, because she doesn't like it (A9).

Children/adolescents also reported a different way of caring/playing with their disabled brother or sister. The 
choice of toys throughout the interpretation made this distinction clear. Thus, all participants reported playing with their special brother or sister using a ball, cart, doll, various objects, colored pencils, paper; and/or playing crawl, school, doctor, in addition to watching TV and listening to music, in addition to playing games such as hide and seek and tag. In this premise, the way of caring is not only the way of being with someone, but being-with-someone. Help the other to be, bet on someone, watch over the integrity and unity of their being ${ }^{(7)}$.

Leisure protects the development of the child/adolescent, it is configured as a moment of rest, socialization and development of skills and autonomy. In this context, there is a self-fulfillment, a way to compensate their needs. However, these aspects are positive, as adolescents especially acquire greater visibility of expression, daily producing their own cultural norms and expressions ${ }^{(18)}$.

The human being is open to his surroundings, to the world, to his fellow man, to his neighbor. Such openness, or eccentricity, is an element that constitutes the human being, in which the center of life is not the self, but the you. An opening of oneself to the other, in an open and emphatic interpersonal relationship that only happens in the encounter with the other ${ }^{(7)}$. The opening of the I with the you enables the understanding that we are beings with-each-other, and from the other, the being understands itself and the world:

\begin{abstract}
The Dasein, according to its own way-of-being, tends to understand its own being from the entity in relation to which it, in a constant and immediate way, essentially behaves: from the "world". [...] because to Dasein, the understanding-of-being is not only inherent, but it is elaborated and undone according to what is each time Dasein's way-of-being, [...] it is certain that it belongs to the most-self-being to have an understanding of this being, maintaining itself each time in an interpretation of its being ${ }^{(6: 69-70)}$.
\end{abstract}

In the act of playing, children/adolescents open up to new possibilities and are constituted by the relationships they establish during play. All the siblings play, the firstborn take care of the youngest, however, children/adolescents who live with their disabled sibling take care of them, regardless of whether they are firstborn or not. What often differs, depending on the grade of the sibling's disability, is the type of play, which occurs in a shared way with children/adolescents who do not live with their disabled sibling. Therefore, the child/adolescent who lives with their disabled sibling often needs to give up their favorite games to do those the sibling likes ${ }^{(19)}$.
Still, in this context, the weaving of the act of caring takes place, in the Heideggerian view: All behaviors of the being are ontically "concerned" and driven by a "delivery" to something ${ }^{(6: 555)}$ [...] a knowledge in which the being-there understands. Solicit care is understood at the level of what is being cared for, together with the understanding that one has of it. Thus, the other is immediately unveiled in careful solicitude ${ }^{(6)}$.

Therefore, it is understood that care takes place in the various dimensions of being-with-the-other in their way of being and being constituted by this way of being-at-withthe-other. All ways of caring, from playing to more complex activities such as helping with the bath, feeding, preparing the baby bottle, helping with school tasks, are ways of solicitude. In this context, it is necessary to 'look' at this child/ adolescent who cares, but who also needs care.

\section{FINAL CONSIDERATIONS}

Based on the reports and information provided, it was possible to understand the meaning that the child/adolescent attributes to their participation in the care provided to their disabled sibling, as well as the different ways in which this cooperation takes place amid daily life and the singularity of each family.

It is observed that the sibling participates in the care in different situations, helping the main caregiver, in this research described as the mother, in the daily care tasks, thinking that she is helping and not being alone in her action, she is willing and able to care through playful activities, and through them reveal possible hidden desires such as the cure of her disabled sibling. Care is also evidenced through activities related to the learning process. The'caring' process sometimes brings 'overload' to the sibling when he goes beyond the act of playing and is unveiled as a responsibility to be performed during the absence of the main caregiver.

It is highlighted the importance of planning and implementing a unique care with intuition and sensitivity, developed by health professionals and especially nurses, with a focus on people with disabilities, their siblings and their families, prioritizing the construction of strategies that help with daily activities and minimize the daily burden of the mother as the main caregiver and the siblings.

It is believed that health professionals can form support networks, organizing the care demands of people with disabilities, to optimize the access of families to health services, in cases where periodic and sporadic follow-up is necessary, such as consultations with doctors, dentists, nutritionists, psychologists, in addition to nursing care and physiotherapy. Furthermore, optimizing access to tests and 
treatments, streamlining processes, can favor care, minimizing the burden on mothers and siblings. Also, pay attention to the effectiveness of current public policies, with a focus on prevention, protection and health promotion, considering the unveiled phenomena of the experiences of each being, understanding that care permeates an existential dimension, which has no predetermination.

One of the limitations of the study is the fact that it was carried out only with the siblings, and the inclusion of the main caregiver acting in this context could contribute to broadening the perception of the issue. It is expected that this study will encourage discussions about how the care of children with disabilities is being carried out. It is highlighted as a contribution of the research the qualification of the practice of health professionals, especially the nurse in the context of care for the child/adolescent who lives in these contexts.

\section{REFERENCES}

1. Freitag VL, Milbrath VM, Motta MGC. The mother-caregiver of child/teenager with cerebral palsy: taking care of herself. Enferm Global, 2018;17(50):325-60. doi: https://doi.org/10.6018/eglobal.17.2.265821

2. Batista BR, Duarte M, Cia F. A interação entre as pessoas com síndrome de Down e seus irmãos: um estudo exploratório. Ciênc Saúde Coletiva. 2016;21 (10):3091-9. doi: https://doi.org/10.1590/1413-812320152110.17282016

3. Blanco MJM. Hermanos... los grandes olvidados/Siblings... the greatly forgotten. Rev Esp Pediatr Clin Invest. 2015 [cited 2020 Mar 10];71(supl.1):76-9. Available from: https://www.seinap.es/wp-content/uploads/Revista-de-Pediatria/2015/ REP\%2071-Supl\%201.pdf

4. Hsiao CY, Lee CT, Lu HL, Tsai YF. Living with schizophrenia: health-related quality of life among primary family caregivers. J Clin Nurs. 2017;26(23-24):5151-9. doi: https://doi.org/10.1111/jocn.14063

5. Havill N, Fleming LK, Knafl K. Well siblings of children with chronic illness: a synthesis research study. Res Nurs Health. 2019;42(5):334-48. doi: https://doi. org/10.1002/nur.21978

6. Heidegger M. Ser e tempo. 8a ed. Petrópolis (RJ):Vozes; 2012.

7. Roselló FT. Antropologia do cuidar. 1a ed. Petrópolis (RJ): Vozes; 2009.
8. Freitag VL. Ser-no-mundo da criança/adolescente que convive com irmão com deficiência: uma abertura para a autenticidade [tese]. Porto Alegre (RS): Escola de Enfermagem, Universidade Federal do Rio Grande do Sul; 2020.

9. Moreno López S. La entrevista fenomenológica: una propuesta para la investigación en psicología y psicoterapia. Rev Abord Gestáltica: Phenomenol Stud. 2014 [cited 2020 ar 20];20(1):63-70. Available from: https://www.redalyc.org/ pdf/3577/357733920009.pdf

10. Ricouer P. 0 conflito das interpretaçoes: ensaios de hermenêutica. Rio de Janeiro (RJ): Imago; 1978.

11. Milbrath, VM. Criança/adolescente com paralisia cerebral: compreensões do seu modo de ser no mundo [tese]. Porto Alegre (RS): Escola de Enfermagem, Universidade Federal do Rio Grande do Sul; 2013.

12. Boff L. Saber cuidar: ética do humano: compaixão pela terra. 20a ed. São Paulo: Petrópolis (RJ): Vozes; 2014.

13. Vella Gera J, Martin GM, Zahra AJC. An insight into the lives of young siblings of disabled children in Malta. Disabil Soc. 2020;36(1):58-80. doi: https://doi.org/ 10.1080/09687599.2020.1712188

14. Shivers CM, Jackson JB, McGregor CM. Functioning among typically developing siblings of individuals with autism spectrum disorder: a meta-analysis. Clin Child Fam Psychol Rev. 2019;22(2):172-96. doi: http://doi.org/10.1007/ s10567-018-0269-2

15. Osher D, Cantor P, Berg J, Steyer L, Rose T. Drivers of human development: how relationships and context shape learning and development. Appl Dev Sci. 2020;24(1):6-36. doi: https://doi.org/10.1080/10888691.2017.1398650

16. García-Pulido EA. El profesional de enfermería ante la claudicación familiar. Rev Enferm Ins. Mex Seguro Soc. 2019 [cited 2020 Mar 10];27(4):182-7 [editorial]. Available from: http://revistaenfermeria.imss.gob.mx/editorial/index.php/ revista_enfermeria/article/view/915/1042

17. Zaidman-Zait A, Yechezkiely M, Regev D. The quality of the relationship between typically developing children and their siblings with and without intellectual disability: Insights from children's drawings. Res Dev Disabil. 2020;96:103537. doi: https://doi.org/10.1016/j.ridd.2019.103537

18. Silva DAM, Souza MH. E o lazer na construção do jogo do saber?? ninguém sabe, ninguém viu!!! Licere. 2017;20(4):186-211. doi: https://doi. org/10.35699/1981-3171.2017.1731

19. McHale SM, UpdegraffKA, Feinberg ME. Siblings of youth with autism spectrum disorders: theoretical perspectives on sibling relationships and individual adjustment. J Autism Dev Disord. 2016;46(2):589-602. doi: https://doi. org/10.1007/s10803-015-2611-6 


\section{- Acknowledgment:}

To the Coordination for the Improvement of Higher Education Personnel (Coordenação de Aperfeiçoamento de Pessoal de Nivel Superior - CAPES) for granting the scholarship during the doctorate (PPGEnf/UFRGS, 2016-2019).

\section{- Authorship contribution:}

Vera Lucia Freitag: Conceptualization, Data curation, Formal analysis, Funding acquisition, Investigation, Methodology, Project administration, Resources, Software, Supervision, Validation, Visualization, Writingoriginal draft, Writing-review \& editing.

Maria da Graça Corso da Motta: Conceptualization,

Data curation, Formal analysis, Funding acquisition, Methodology, Project administration, Supervision, Validation, Visualization, Writing-original draft, Writingreview \& editing.

Viviane Marte Milbrath: Data curation, Formal analysis, Methodology, Supervision, Validation, Visualization, Writing-original draft, Writing-review \& editing. Ruth Irmgard Bärtschi Gabatz: Formal analysis, Methodology, Validation, Visualization, Writing-original draft, Writing-review \& editing.

Jéssica Stragliotto Bazzan: Formal analysis, Visualization, Writing-original draft, Writing-review \& editing.

The authors declare that there is no conflict of interest.

\section{- Corresponding author:}

Vera Lucia Freitag

E-mail: verafreitag@hotmail.com

Associate editor:

Wiliam Wegner

Approved: 01.12.2021

Editor-in-chief:

Maria da Graça Oliveira Crossetti 